\title{
Best practices to prevent transmission and control outbreaks of hand, foot, and mouth disease in childcare facilities: a systematic review
}

\author{
Joyce HY Chan *, CK Law, Esther Hamblion, H Fung, James Rudge
}

\section{A B S T R A C T}

Introduction: Hand, foot, and mouth disease continues to cause seasonal epidemics in the AsiaPacific Region. Since the current Enterovirus 71 vaccines do not provide cross-protection for all Enterovirus species that cause hand, foot, and mouth disease, there is an urgent need to identify appropriate detection tools and best practice to prevent its transmission and to effectively control its outbreaks. This systematic review aimed to identify characteristics of outbreak and assess the impact and effectiveness of detection tools and public health preventive measures to interrupt transmission. The findings will be used to recommend policy on the most effective responses and interventions in Hong Kong to effectively minimise and contain the spread of the disease within childcare facilities.

Methods: We searched the following databases for primary studies written in Chinese or English: MEDLINE, EMBASE, Global Health, WHO Western Pacific Region Index Medicus database, China National Knowledge Infrastructure Databases, and Chinese Scientific Journals Database. Studies conducted during or retrospective to outbreaks of hand, foot, and mouth disease caused by Enterovirus 71 from 1980 to 2012 within childcare facilities and with a study population of 0 to 6 years old were included.

Results: Sixteen studies conducted on outbreaks in China showed that hand, foot, and mouth disease spread rapidly within the facility, with an outbreak length of 4 to 46 days, especially in those with delayed notification (after 24 hours) of clustered

This article was published on $17 \mathrm{Mar}$ 2017 at www.hkmj.org. outbreak (with five or more cases discovered within the facility) to the local Center for Disease Control and Prevention and delayed implementation of a control response. The number of classes affected ranged from 1 to 13 , and the attack rate for children ranged from $0.97 \%$ to $28.18 \%$.

Conclusions: Communication between key stakeholders about outbreak confirmation, risk assessment, and surveillance should be improved. Effective communication facilitates timely notification (within 24 hours) of clustered outbreaks to a local Center for Disease Control and Prevention. Timely implementation of a control response is effective in minimising incidence and length of an outbreak in childcare facilities. The government should provide incentives for childcare facilities to train infection control specialists who can serve as the first contact, knowledge, and communication points, as well as facilitate exchange of information and provision of support across stakeholders during a communicable disease epidemic.

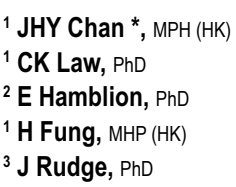
The Jockey Club School of Public Health and Primary Care, The Chinese University of Hong Kong, Shatin, Hong Kong
2 Independent Consultant Epidemiologist, London, United Kingdom Communicable Diseases Policy Research Group, Department of Global Health and Development, London School of Hygiene and Tropical Medicine, Bangkok Office, Thailand
* Corresponding author: hychan@cuhk.edu.hk

\section{Introduction}

Hand, foot, and mouth disease (HFMD) is an increasing burden in the Western Pacific Region including Australia, Brunei Darussalam, China, Japan, Malaysia, Mongolia, the Republic of Korea, Singapore, and Vietnam with 3 million cases and 400 deaths reported in $2014 .{ }^{1}$ It is a common infection in children aged between 1 and 5 years during the hot and humid season across East and South-East Asia. ${ }^{1,2}$ Transmission of HFMD is increased in crowded and closed environments, such as kindergartens or child daycare centres, where infectious droplets can easily spread via sharing of objects or surfaces (fomites). ${ }^{3}$ In 2014, China accounted for nearly a third of this burden with 2.6 million HFMD cases and 371 deaths. ${ }^{1}$ Hong Kong, a Special Administrative Region (HKSAR) of China, has also been affected by HFMD outbreaks. In 2015, there were around 700 institutional HFMD outbreaks affecting 4200 Hong Kong people; $60 \%$ of which occurred in childcare 


\section{預防及控制手足口病在幼稚園或幼兒中心傳播的 最佳方法：系統性文獻回顧 \\ 陳巧瑩、羅智健、Esther Hamblion、馮康、James Rudge}

引言：手足口病在亞太地區是一種季節性流行病。由於目前的腸道病 毒71型滅活疫苗未能為所有引致手足口病的腸病毒發揮保護作用, 務 必盡快找出合適的檢測工具, 以及制定預防及控制手足口病傳播的最 佳方法。本文旨在找出此病爆發的特點, 並評估其檢測工具和採取的 公共衛生措施對於阻止病症爆發的影響和效用。研究結果將可以為香 港制定最有效的對策和預防措施提出建議, 使能有效減少和控制此病 在幼稚園或幼兒中心傳播。

方法：通過以下數據庫搜索有關手足口病研究的中英文文 獻：MEDLINE、EMBASE、Global Health、WHO Western Pacific Region Index Medicus、中國學術期刊全文數據庫 (CNKI) 和中文科 技期刊數據庫（CSJD-VIP）。研究範圍是在1980年至2012年期間在 幼稚園或幼兒中心曾因腸道病毒 71 引致手足口病的爆發, 並在爆發期 間或期後進行的研究。研究中的患者均為 0 至 6 歲的兒童。

結果：共16項研究均於國內進行。綜合結果顯示手足口病在幼稚園 或幼兒中心內會迅速傳播, 爆發期由 4 至 46 天不等。在那些出現聚集 性爆發（即在一個院校內有5個或以上的病例）並延遲通知（24小時 後）當地疾病預防控制中心, 且較遲實施控制措施的院校內爆發的速 度尤其快。受影響的班級數目介乎 1 至 13 班, 兒童發病率則介乎 $0.97 \%$ 至28.18\%。

結論：有必要改善主要持分者之間以下幾方面的溝通, 包括爆發確 認、風險評估和緊密監控。有效的溝通才可以加快並及時通知（24 小時內）疾病預防控制中心有關的爆發事件。盡快採取控制措施可有 效地減少幼兒設施內手足口病的發生率和持續時間。政府應鼓勵幼稚 園或幼兒中心培訓傳染病控制專家, 讓他們作首個聯繫、知識和交流 點，在傳染病流行期間促進不同持分者之間交流信息和提供支援。 centres or kindergartens. ${ }^{4}$

Hand, foot, and mouth disease is caused by viruses belonging to the Enterovirus genus, such as Coxsackievirus A16 (CA16) and Enterovirus 71 (EV71). In the Western Pacific Region of the World Health Organization (WHOWPR), infections with high severity and complications are mainly associated with EV71..$^{5-7}$ Outbreaks of EV71 in the region have been identified in $41 \%$ of HFMD cases, $81 \%$ of severe cases, and $93 \%$ of deaths, resulting in higher rates of complications, neurological disease, and fatalities compared with other causative agents such as CA16. ${ }^{6,8-12}$ It is therefore important to distinguish EV71 from other HFMD strains during the outbreak. ${ }^{13}$

In 2011, following the emergence of HFMD outbreaks throughout the Western Pacific Region, the HKSAR Government announced EV71 infection as one of the 47 statutorily notifiable communicable diseases under the Prevention and Control of Disease Ordinance (Central Notification Office) ${ }^{14}$ According to HFMD outbreak management practices issued by the WHO, the HKSAR Centre for Health Protection (CHP) issued guidelines and letters to all childcare facilities, specifically describing management plans in the event of a suspected EV71 outbreak, including steps and standard forms for notification of suspected outbreaks. They also recommended that public health control measures be implemented, namely promoting personal and hand hygiene, regular body checks, environmental disinfection, full or partial closure of the facility, and sentinel surveillance. ${ }^{6,14}$ Despite efforts of the HKSAR Government and health education through public media over the years, institutional outbreaks of HFMD have continued to occur within childcare facilities during the summer and winter periods with approximately 780,350 , and 700 outbreaks in 2013, 2014, and 2015, respectively. ${ }^{4}$ The outbreak size ranged from 2 to 56 persons (median, 4 persons). ${ }^{4}$ Among them, EV71 accounted for $19 \%$ of cases in 2014 but only $8 \%$ in $2015 .{ }^{4}$ No fatal case was reported in 2015 , but $86 \%$ of EV71 cases required hospitalisation and $11 \%$ developed severe complications such as encephalitis, meningitis, and cerebellitis albeit with no longterm neurological consequences. ${ }^{4}$ The burden of HFMD remains prevalent among young children in institutional settings. ${ }^{15}$

Given the health and social impact in the Western Pacific Region, China, Taiwan, and Singapore started developing EV71 vaccines for children under 5 years old. ${ }^{16}$ Three vaccines that provided more than $90 \%$ protection against EV71associated HFMD for children under 5 years old were granted a license from the China Food and Drug Administration in 2014..$^{16,17}$ Nonetheless, despite their clinical efficacy, they could not provide cross-protection across other Enterovirus species such as CA16, one of the main agents responsible for HFMD outbreaks throughout the Western Pacific Region. ${ }^{16}$ It remains a challenge to control HFMD outbreaks at a community or institutional level that are often caused by multiple Enterovirus strains. Past studies suggested that early implementation of outbreak management practices can be effective in minimising HFMD spread. ${ }^{3,7,18,19}$ There has been no comprehensive systematic review of evidence from HFMD outbreaks, however, to elucidate the most important factors for outbreak control.

We performed a systematic review to identify, collate, and review the current evidence for the effectiveness of public health measures and diagnostic tools to control and interrupt HFMD transmission among young children in childcare facilities. In this study, childcare facilities included kindergartens, playgroups, nurseries, preschool facilities, and child daycare centres. The evidence will be used to inform practice and recommend policy on the most effective responses and interventions in 
the HKSAR to effectively minimise and contain the spread of HFMD within childcare facilities.

\section{Methods}

\section{Data sources and search strategies}

We conducted electronic searches of the following databases for primary studies written in Chinese or English: MEDLINE (1946 to present), EMBASE (1980 to 6 April 2012), and Global Health (1973 to March 2012). Databases specific to South-East Asia were also interrogated including the WHO Western Pacific Region Index Medicus database and countryspecific databases within China-China National Knowledge Infrastructure Databases (CNKI; www. cnki.net) [1989 to 2012] and Chinese Scientific Journals Database (CSJD-VIP; www.cqvip.com) [1990 to 2012]. We searched the database with the medical subject headings or key words "hand foot and mouth disease", "child care facilities", "prevention and control", "outbreak notification", "molecular diagnostic technique", and "morbidity and mortality". Searches were supplemented by references identified from reference lists of all included papers. To ensure that no relevant studies were missed, the following websites were also browsed: Centre for Health Protection (www.chp.gov.hk/), World Health Organization (www.who.int/), and WHO Western Pacific Region (www.wpro.who.int/) for relevant reports and grey literature.

\section{Study selection}

We included studies conducted during or retrospective to HFMD outbreaks caused by EV71 from 1980 to 2012 within childcare facilities, with a study population within the age range of 0 to 6 years. Studies with a description of public health control measures implemented and diagnostic methods used to isolate EV71 from the HFMD outbreaks, with findings supported by empirical data in text or figures were included.

Identified studies were saved in endnote and duplicate studies removed. The titles and abstracts were screened for relevance and eligible full-text papers obtained and reviewed. Studies without the availability of full text were excluded as were those that did not fulfil the inclusion criteria after full-text review.

\section{Data extraction}

Two researchers extracted the data on outbreak characteristics, methods for detection and diagnosis of EV71, interventions applied, and recommendations for dealing with future outbreaks. Assessment of methodological quality was based on study design, population settings, outcome, interventions, strengths, weaknesses, and areas of potential bias using the method recommended by Critical Appraisal Skills Programme (CASP). ${ }^{20}$ Ratings of 'good', 'satisfactory', and 'poor' were assigned according to the number of criteria fulfilled. A modified quality assessment tool for systematic reviews of observational studies (QATSO) checklist $^{21}$ was also developed for this review to assess external validity, reporting bias, and confounding. This was used to generate QATSO scores for each domain. The studies were appraised according to objectives to see if they provided sufficient evidence to measure the impact and effectiveness of detection tools and public health control measures during the HFMD outbreak. Recommendations for dealing with future outbreaks were extracted from the studies and examined for relevance to the childcare setting in Hong Kong.

\section{Results}

\section{Search results}

The Figure depicts the search and selection process which identified 16 studies that met the inclusion criteria. All studies were conducted on outbreaks in China-14 were case-series studies (located in Beijing City, Dafeng City, Dalian City, Jining City, Laiwu City, Langfang City, Qianjiang City, Shanghai City, Shenzhen City, Zhengzhou City), and two were mixed case-control and case-series studies (located in Shenzhen and Zhengzhou City). Of the 16 studies, two investigated clustered outbreaks involving multiple (7 and 61) kindergartens, ${ }^{22,23}$ and the other 14 studies each focused on an outbreak within a single kindergarten..$^{24-37}$ Of the included articles, 15 were published by the Chinese Center for Disease Control and Prevention (China CDC) $22-34,36,37$ and one by a local hospital as an outbreak investigation report. ${ }^{35}$ All included articles were published in Chinese, with some of them having an English abstract.

\section{Quality appraisal of included studies}

The methodological quality of included studies was moderate to good based on the CASP assessment, with three, six, and seven studies scoring 2, 3, and 4 (out of 5 ), respectively. The most common weaknesses across studies were insufficient data and discussion of the role, impact, and effectiveness of detection tools and control measures in controlling HFMD outbreak (Table $1^{22-37}$ ).

The 14 descriptive case-series studies included in this review can be classified as level IV evidence, which is the lowest tier of the evidence hierarchy proposed by the National Health and Medical Research Council. ${ }^{38}$ The two studies that involved a case-control design to identify risk factors of HFMD can be classed as level III-2 evidence. ${ }^{38}$ There was potential for selection bias as the participating 


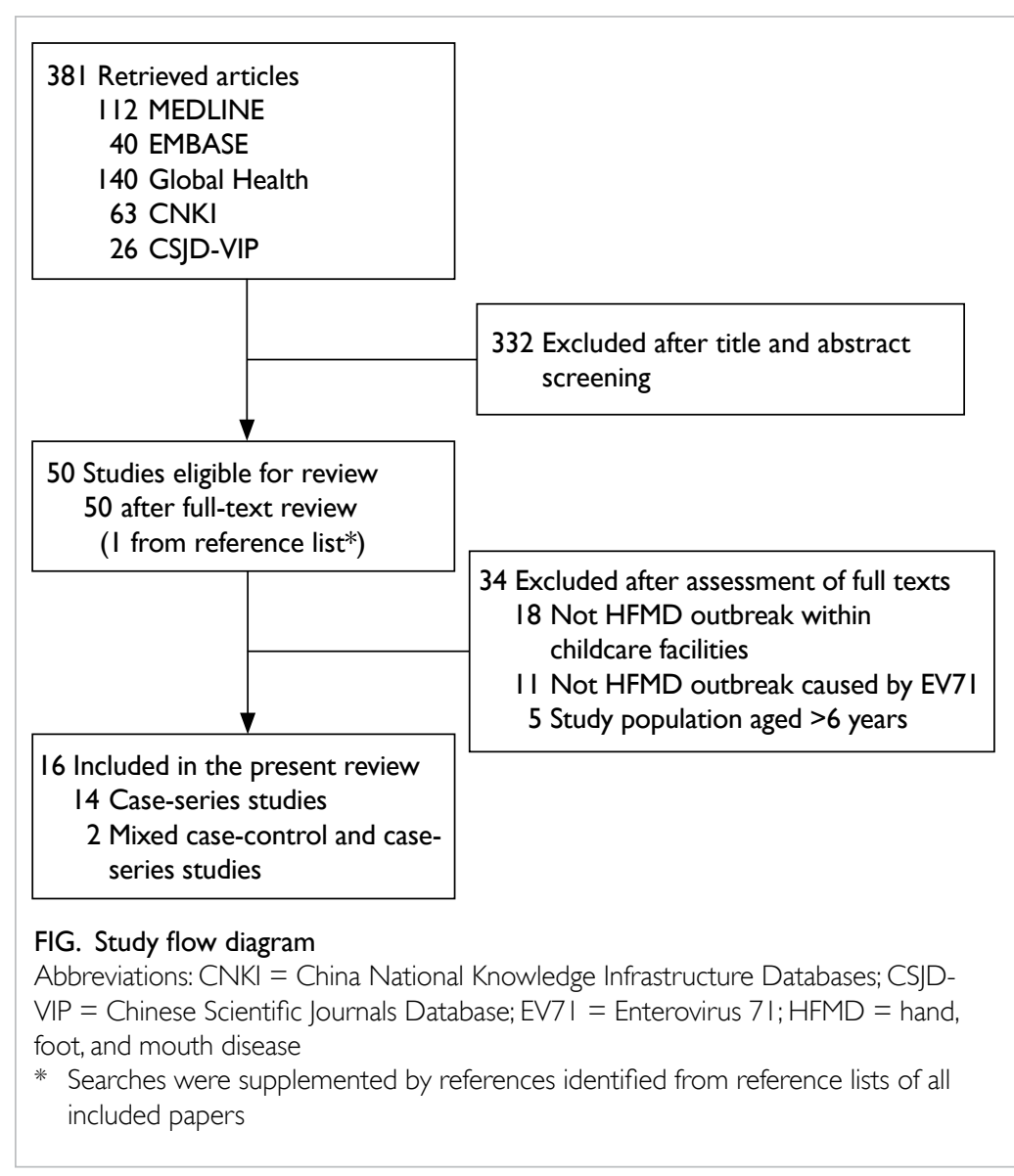

kindergartens were not randomly selected. Moreover, there was likely detection bias as the majority of specimens were collected only from symptomatic children. Also, reporting bias is present due to different versions $(2008,2009$, or 2012 versions) of the China CDC guidelines being applied and different outcome definitions being used across studies. All included studies scored good (QATSO score, 67\%$100 \%)$ in the QATSO bias assessment. Most of the included studies were outbreak investigation reports and did not mention a sampling method. Laboratory tests were used to measure the study objective for the effectiveness of the detection tool. The response rate of study participants was not applicable to the epidemiological investigation (case series) reports. It was only applicable in two case-control studies. For HFMD cases, all studies used the anonymous or surname only to describe HFMD cases to protect their privacy. The sensitivity regarding HFMDaffected cases, and kindergarten anonymity was carefully considered and confidentiality maintained even in risk communication among the public in different regions of China.

\section{Synthesis of evidence Population}

A majority of studies gave few or no details about the childcare facility. Only eight studies, covering a total of 14 outbreaks, reported whether they were public or private facilities (four and 10 outbreaks, respectively)..$^{22-24,27-30,35}$ Three outbreaks were reported in an urban area, ${ }^{28,29,32}$ and not specified for the other outbreaks. In China, a city or district may include counties, towns and villages, and encompass both urban and rural areas. Therefore it was difficult to distinguish the nature of the kindergarten when it was not specified. ${ }^{39}$ The study population for the individual outbreaks ranged from 102 to 889 children and for the clustered outbreaks in 7 and 61 kindergartens, the study sizes were 830 and 16780 children, respectively (Table $2^{22-37}$ ).

\section{Characteristics of outbreaks}

Of the included studies, 15 reported length of outbreak, with a mean and median of 15 days, and a range of 4 to 46 days. Minor variations were seen in the definition of length of outbreak applied. Of the 14 individual outbreaks, 11 (78.6\%) were reported to occur between March and June (Table $2^{22-37}$ ). The timing of the clusters of outbreaks that were examined in two articles also included these months. Different rates of HFMD were reported across studies, with a mean attack rate of $8.4 \%$ (range, $0.97 \%-28.18 \%$ ), a mean severe case rate of 5.3\% (range, 0\%-50\%), and a mean hospitalisation rate of $2.8 \%$ (range, $0 \%-33.86 \%$ ). The majority of the sampled cases were symptomatic except for the report of an asymptomatic healthy carrier in a study by Wang et al. ${ }^{29}$ No deaths were reported in any of the included studies.

Attack rate of HFMD was significantly higher among children aged 2 to 3 years than those aged 4 to 6 years. Individual attack rates for those aged 2, $3,4,5$, and 6 years were $2.4 \%, 2.95 \%, 1.15 \%, 0.72 \%$, and $0.39 \%$, respectively (Chi squared $=143.58$ ) at $\mathrm{P}<0.05$ level. ${ }^{22} \mathrm{Li}$ et $\mathrm{al}^{25}$ revealed that children who were admitted to kindergarten between 2 and 3 years (odds ratio $[\mathrm{OR}]=7.0 ; 95 \%$ confidence interval $[\mathrm{CI}]$, 1.2-46; $\mathrm{P}=0.01)$ and had contact with symptomatic cases $(\mathrm{OR}=6.75 ; 95 \% \mathrm{CI}, 1.15-44 ; \mathrm{P}=0.01)$ posed a 7-times higher risk for HFMD infection.

A majority of studies did not provide sufficient data for assessment of delay between index case, notification of CDC, and specimen collection (Table $3^{22-37}$ ). Across the three studies in which data were available, the time between index case and reporting to CDC varied widely, from just a single day in one study to over 2 weeks in the other two studies. ${ }^{34,36,37}$ The "timely" or "delayed" description summarised in Table 3 is based on study text that reflected the China CDC guidelines. ${ }^{24,30,32,33}$ Across the five 
TABLE I. Quality appraisal of included studies ${ }^{22-37}$

\begin{tabular}{|c|c|c|c|}
\hline Study & Weakness* & CASP score & QATSO score‡ \\
\hline Li et $a l,{ }^{37} 2011$ & $\begin{array}{l}\text { Lack of data and in-depth discussion of control measures and their impact and } \\
\text { effectiveness in the specific HFMD outbreak }\end{array}$ & 2/5 Satisfactory & 2/3 Good \\
\hline Tao et al, ${ }^{28} 2009$ & $\begin{array}{l}\text { Lack of data and in-depth discussion of detection tools and their role and impact } \\
\text { in HFMD outbreak control. Insufficient data to assess effectiveness of detection } \\
\text { tools and control measures }\end{array}$ & 4/5 Good & 2/3 Good \\
\hline Li et $a l,{ }^{26} 2008$ & $\begin{array}{l}\text { Lack of data and in-depth discussion of detection tools and their role and impact } \\
\text { in HFMD outbreak control. Insufficient data to assess effectiveness of detection } \\
\text { tool and control measures. Confounding factors were not considered when } \\
\text { analysing the association }\end{array}$ & 4/5 Good & 3/4 Good \\
\hline Duan et al,22 2010 & $\begin{array}{l}\text { Lack of data and in-depth discussion of detection tools and their role and impact } \\
\text { in HFMD clustered outbreak control. Insufficient data to assess effectiveness of } \\
\text { detection tool and control measures }\end{array}$ & 4/5 Good & 2/3 Good \\
\hline Jiang, ${ }^{24} 2011$ & $\begin{array}{l}\text { Lack of data and in-depth discussion of detection tool and its role and impact in } \\
\text { HFMD outbreak control }\end{array}$ & 4/5 Good & 2/3 Good \\
\hline Chen et al, ${ }^{36} 2007$ & $\begin{array}{l}\text { Lack of data and in-depth discussion of detection tool and its role and impact in } \\
\text { HFMD outbreak control }\end{array}$ & 4/5 Good & 2/3 Good \\
\hline Wang et al, ${ }^{29} 2010$ & $\begin{array}{l}\text { Missing data for important outbreak characteristic, eg male-to-female ratio } \\
\text { of attack rate. Lack of in-depth discussion of detection tool and its role, } \\
\text { effectiveness, and impact in HFMD outbreak control }\end{array}$ & 2/5 Satisfactory & 2/3 Good \\
\hline $\mathrm{Wu},{ }^{30} 2011$ & $\begin{array}{l}\text { Lack of data and in-depth discussion of detection tools and their role and impact } \\
\text { in HFMD clustered outbreak control. Insufficient data to assess effectiveness of } \\
\text { detection tool and control measures }\end{array}$ & 4/5 Good & 2/3 Good \\
\hline Qu, ${ }^{23} 2010$ & $\begin{array}{l}\text { Missing data for crucial outbreak characteristic for individual outbreaks, eg male- } \\
\text { to-female ratio of attack rate. Insufficient data for detection tool, and its role, } \\
\text { effectiveness, and impact in HFMD outbreak control }\end{array}$ & 4/5 Good & 2/3 Good \\
\hline Li et al, ${ }^{25} 2010$ & $\begin{array}{l}\text { Lack of data and in-depth discussion of detection tools and their role and impact } \\
\text { in HFMD clustered outbreak control. Insufficient data to assess effectiveness of } \\
\text { detection tool and control measures. Confounding factors were not considered } \\
\text { when analysing the association }\end{array}$ & 2/5 Satisfactory & 2/3 Good \\
\hline Lu et al, ${ }^{27} 2008$ & $\begin{array}{l}\text { Lack of data and in-depth discussion of detection tools and their role and impact } \\
\text { in HFMD clustered outbreak control. Insufficient data to assess effectiveness of } \\
\text { detection tool and control measures }\end{array}$ & 3/5 Good & 2/3 Good \\
\hline Ge and Lu, ${ }^{35} 2010$ & $\begin{array}{l}\text { Lack of data and in-depth discussion of detection tools and their role and impact } \\
\text { in HFMD clustered outbreak control. Insufficient data to assess effectiveness of } \\
\text { detection tool and control measures }\end{array}$ & 3/5 Good & 2/3 Good \\
\hline Yu et al, ${ }^{31} 2009$ & $\begin{array}{l}\text { Lack of data and in-depth discussion of detection tools and their role and impact } \\
\text { in HFMD outbreak control. Insufficient data to assess effectiveness of detection } \\
\text { tool and control measures }\end{array}$ & 3/5 Good & 2/3 Good \\
\hline $\begin{array}{l}\text { Zhang and Qin, }{ }^{32} \\
2007\end{array}$ & $\begin{array}{l}\text { Lack of data and in-depth discussion of detection tools and their role and impact } \\
\text { in HFMD outbreak control. Insufficient data to assess effectiveness of detection } \\
\text { tool and control measures }\end{array}$ & 3/5 Good & 2/3 Good \\
\hline $\begin{array}{l}\text { Zhang and Ren, } \\
2010\end{array}$ & $\begin{array}{l}\text { Lack of data and in-depth discussion of detection tools and their role and impact } \\
\text { in HFMD outbreak control. Insufficient data to assess effectiveness of detection } \\
\text { tool and control measures }\end{array}$ & 3/5 Good & 2/3 Good \\
\hline Zhang et al, ${ }^{34} 2001$ & $\begin{array}{l}\text { Provided data for effectiveness of detection tool only. Lack of in-depth discussion } \\
\text { of its role and impact in HFMD outbreak control }\end{array}$ & 3/5 Good & 2/3 Good \\
\hline
\end{tabular}

Abbreviations: CASP = Critical Appraisal Skills Programme; EV7I = Enterovirus 7I; HFMD = hand, foot, and mouth disease; QATSO = quality assessment tool for systematic reviews of observational studies

* Potential selection bias for all included studies: non-randomised study; potential detection bias for EV7I: only specimens from symptomatic cases were collected for analysis

† CASP score domains: recruitment strategy, data collection, data analysis, clear finding, further research

‡ QATSO score domains: sampling, objective measurement, response rate, confounding, sensitivity

studies for which data were available, the mean time between index case and specimen collection was 12 days (range, 5 - 25 days). ${ }^{24,32,34,36,37}$

\section{Specimen collection}

A total of 315 specimens of five different types were collected across the studies. Of these, $56.8 \%$ were stool samples, $14.0 \%$ blood samples, $12.7 \%$ anal swabs, $8.6 \%$ throat swabs, $0.6 \%$ oral rinse samples, and $7.3 \%$ unspecified. As shown in Table 3, one study collected samples from a selection of symptomatic and asymptomatic cases (method of selection not 
TABLE 2. Outbreak characteristics of included studies ${ }^{22-37}$

\begin{tabular}{|c|c|c|c|c|c|c|c|c|c|c|}
\hline Study & Location & $\begin{array}{l}\text { Length of } \\
\text { outbreak* } \\
\text { (days) }\end{array}$ & $\begin{array}{l}\text { Study size } \\
\text { (No. of } \\
\text { children) }\end{array}$ & $\begin{array}{l}\text { No. of } \\
\text { cases }\end{array}$ & $\begin{array}{c}\text { Mean } \\
\text { (range) } \\
\text { age } \\
\text { (years) }\end{array}$ & $\begin{array}{c}\text { Attack rate } \\
(\%)\end{array}$ & $\begin{array}{l}\text { No. of } \\
\text { classes } \\
\text { affected }\end{array}$ & $\begin{array}{l}\text { Hospital- } \\
\text { isation } \\
\text { rate }(\%)\end{array}$ & $\begin{array}{l}\text { Severe } \\
\text { case } \\
\text { rate }(\%)\end{array}$ & $\begin{array}{c}\text { Time of } \\
\text { year }\end{array}$ \\
\hline $\begin{array}{l}\text { Chen et al, }{ }^{36} \\
2007\end{array}$ & $\begin{array}{l}\text { Guangdong } \\
\text { Province, } \\
\text { Shenzhen City, } \\
\text { Futian District }\end{array}$ & 17 & 689 & 26 & $3(2-6)$ & 3.77 & 4 & 0 & 0 & May to Jun \\
\hline $\begin{array}{l}\text { Duan et al, }{ }^{22} \\
2010\end{array}$ & $\begin{array}{l}\text { Shandong } \\
\text { Province, Jining } \\
\text { City, Shizhong } \\
\text { District }\end{array}$ & $\begin{array}{l}\text { N/A for each } \\
\text { outbreak }\end{array}$ & $16780 \dagger$ & 372 & $2.5(2-6)$ & 2.22 & N/A & 33.86 & 11.81 & Mar to Oct \\
\hline $\begin{array}{l}\text { Ge and Lu, }{ }^{35} \\
2010\end{array}$ & $\begin{array}{l}\text { Shandong } \\
\text { Province, Laiwu } \\
\text { City, Gangcheng } \\
\text { District }\end{array}$ & 16 & 390 & 26 & $3.5(2-5)$ & 6.67 & 10 & 0 & 0 & Oct to Nov \\
\hline Jiang, ${ }^{24} 2011$ & $\begin{array}{l}\text { Henan Province, } \\
\text { Zhengzhou City }\end{array}$ & $>6 \ddagger$ & 685 & 13 & $3(3-5)$ & 14.31 & 4 & 0 & 0 & Jun \\
\hline Li et al, ${ }^{37} 2011$ & Beijing City & 6 & 157 & 6 & $3(2-4)$ & 3.82 & 1 & $\mathrm{~N} / \mathrm{A}$ & 50 & Jun \\
\hline Li et al, ${ }^{25} 2010$ & $\begin{array}{l}\text { Henan Province, } \\
\text { Zhengzhou City }\end{array}$ & 15 & 167 & 15 & $2.5(2-4)$ & 8.98 & 2 & 0 & 0 & Apr \\
\hline Li et al, ${ }^{26} 2008$ & $\begin{array}{l}\text { Guangdong } \\
\text { Province, } \\
\text { Shenzhen City, } \\
\text { Futian District }\end{array}$ & 14 & 382 & 16 & $3.5(3-4)$ & 4.19 & 2 & 0 & 0 & Apr to May \\
\hline Lu et al, ${ }^{27} 2008$ & $\begin{array}{l}\text { Hubei Province, } \\
\text { Qianjiang City, } \\
\text { Jianghan District }\end{array}$ & 20 & 889 & 34 & $2.5(1-6)$ & 3.82 & 13 & 5.88 & 0 & Apr to May \\
\hline Qu, ${ }^{23} 2010$ & $\begin{array}{l}\text { Shandong } \\
\text { Province, Dalian } \\
\text { City, Zhongshan } \\
\text { District }\end{array}$ & $\begin{array}{l}\text { (Outbreaks for } 7 \\
\text { kindergartens): } \\
11,10,15,11 \text {, } \\
11,8,9 \text { days }\end{array}$ & $830 \S$ & 91 & $\mathrm{~N} / \mathrm{A}$ & $\begin{array}{c}10.96 \% \\
\text { (Private 8.4\%, } \\
\text { public 17.94\%) }\end{array}$ & $\mathrm{N} / \mathrm{A}$ & $\mathrm{N} / \mathrm{A}$ & 14.29 & Jun to Aug \\
\hline Tao et al, ${ }^{28} 2009$ & Beijing City II & 4 & 620 & 54 & $3(2-6)$ & 0.97 & 2 & 0 & 0 & Mar \\
\hline $\begin{array}{l}\text { Wang et al, }{ }^{29} \\
2010\end{array}$ & $\begin{array}{l}\text { Guangdong } \\
\text { Province, } \\
\text { Shenzhen City, } \\
\text { New Guangming } \\
\text { District II }\end{array}$ & 46 & 608 & 40 & $4(2-6)$ & 8.88 & 9 & 0 & 0 & Mar to Apr \\
\hline$W u,{ }^{30} 2011$ & $\begin{array}{l}\text { Shanghai City, } \\
\text { Baoshan District }\end{array}$ & 11 & 369 & 19 & $3.5(2-4)$ & 5.15 & 2 & 5.26 & 5.26 & May \\
\hline Yu et al, ${ }^{31} 2009$ & $\begin{array}{l}\text { Beijing City, } \\
\text { Fangshan District }\end{array}$ & 11 & 102 & 16 & $2.5(2-4)$ & 15.69 & 5 & 0 & 0 & May \\
\hline $\begin{array}{l}\text { Zhang and } \\
\text { Qin, }{ }^{32} 2007\end{array}$ & $\begin{array}{l}\text { Jiangsu Province, } \\
\text { Dafeng City (urban } \\
\text { area) \| }\end{array}$ & 15 & 750 & 23 & $3(2-4)$ & 3.10 & 5 & 0 & 0 & Mar \\
\hline $\begin{array}{l}\text { Zhang and } \\
\text { Ren,,33 } 2010\end{array}$ & $\begin{array}{l}\text { Hebei Province, } \\
\text { Langfang City }\end{array}$ & 18 & 213 & 30 & $3(1-5)$ & 14.10 & 4 & 0 & 3.33 & Oct to Nov \\
\hline $\begin{array}{l}\text { Zhang et al, }{ }^{34} \\
2001\end{array}$ & $\begin{array}{l}\text { Shanghai City, } \\
\text { Yangpu District }\end{array}$ & 24 & 110 & 31 & $3(2-3)$ & $\begin{array}{c}28.18 \\
\text { (Children), } 8.33 \\
\text { (teacher) }\end{array}$ & 3 & 0 & 0 & Oct to Nov \\
\hline
\end{tabular}

Abbreviation: $\mathrm{N} / \mathrm{A}=$ not available

* Date of index case report to last case recovered

† Clustered outbreaks from 61 kindergartens

$\mp$ Report of last attacked case, not mentioned when last case recovered

$\S$ Clustered outbreaks from 7 kindergartens

\| Urban area reported in the studies 
TABLE 3. Detection method of included studies $22-37$

\begin{tabular}{|c|c|c|c|c|c|c|c|}
\hline \multirow[t]{2}{*}{ Study } & \multirow{2}{*}{$\begin{array}{l}\text { Index case } \\
\text { date }(a 0)\end{array}$} & \multirow{2}{*}{$\begin{array}{l}\text { Date } \\
\text { reported to } \\
\mathrm{CDC}^{*}(\mathrm{a} 1)\end{array}$} & \multirow{2}{*}{$\begin{array}{c}\text { Specimen } \\
\text { collection date (b) }\end{array}$} & \multicolumn{3}{|c|}{ Time (days) } & \multirow[t]{2}{*}{ Detection method } \\
\hline & & & & $\begin{array}{l}\text { From index } \\
\text { case to report } \\
\text { to CDC (a1-a0) }\end{array}$ & $\begin{array}{l}\text { From index } \\
\text { case to } \\
\text { specimen } \\
\text { collection } \\
\text { (b-a0) }\end{array}$ & $\begin{array}{l}\text { From CDC } \\
\text { report to } \\
\text { specimen } \\
\text { collection } \\
\text { (b-a1) }\end{array}$ & \\
\hline Chen et al, ${ }^{36} 2007$ & 26 May 2006 & 10 Jun $2006 †$ & Before 20 Jun 2006 & 15 & $<25$ & $<10$ & NP \\
\hline Duan et al,,22 2010 & $\begin{array}{l}\text { Mar to Sep } \\
2009\end{array}$ & NP & NP & - & - & - & NP \\
\hline Ge and Lu, ${ }^{35} 2010$ & 22 Oct 2008 & NP & NP & - & - & - & NP \\
\hline Jiang, ${ }^{24} 2011$ & 13 Jun 2010 & $\dagger$ & 18 Jun 2010 & - & 5 & - & Fluorescent PCR \\
\hline Li et al,, 2011 & 7 Jun 2010 & 8 Jun $2010 \ddagger$ & 13 Jun 2010 & 1 & 6 & 5 & $\begin{array}{l}\text { RT fluorescent } \\
\text { PCR and pathology } \\
\text { isolation }\end{array}$ \\
\hline Li et al, ${ }^{25} 2010$ & 1 Apr 2009 & NP & NP & - & - & - & RT fluorescent PCR \\
\hline Li et al, ${ }^{26} 2008$ & 25 Apr 2008 & NP & NP & - & - & - & RT fluorescent PCR \\
\hline Lu et al, ${ }^{27} 2008$ & 21 Apr 2008 & NP & NP & - & - & - & PCR \\
\hline Qu, ${ }^{23} 2010$ & $\begin{array}{l}1 \text { Jun } 2009 \text { to } \\
18 \text { Aug } 2009\end{array}$ & NP & NP & - & - & - & NP \\
\hline Tao et al, ${ }^{28} 2009$ & 20 Mar 2009 & NP & NP & - & - & - & NP \\
\hline Wang et al, ${ }^{29} 2010$ & 11 Mar 2010 & NP & NP & - & - & - & RT fluorescent PCR \\
\hline$W u,{ }^{30} 2011$ & 6 May 2010 & $\ddagger$ & NP & - & - & - & $\begin{array}{l}\text { Nucleic acid } \\
\text { detection }\end{array}$ \\
\hline Yu et al, ${ }^{31} 2009$ & 9 May 2008 & NP & NP & - & - & - & NP \\
\hline Zhang and Qin, ${ }^{32} 2007$ & 14 Mar 2006 & $\ddagger$ & 22 Mar 2006 & - & 8 & - & NP \\
\hline Zhang and Ren, ${ }^{33} 2010$ & 17 Oct 2008 & $\dagger$ & NP & - & - & - & $\begin{array}{l}\text { Mentioned } \\
\text { laboratory } \\
\text { examination to } \\
\text { isolate pathogen }\end{array}$ \\
\hline Zhang et al, ${ }^{34} 2001$ & 15 Oct 2000 & 1 Nov 2000† & 1 Nov 2000 & 17 & 17 & 0 & $\begin{array}{l}\text { EV71 antibody } \\
\text { detection }\end{array}$ \\
\hline
\end{tabular}

Abbreviations: CDC = Chinese Center for Disease Control and Prevention; EV7I = Enterovirus 7I; NP = not provided; PCR = polymerase chain reaction; $\mathrm{RT}=$ real-time

* According to the CDC's 2012 Management Guide for Clustered Hand foot and Mouth disease outbreak Article 3: When medical institutions, nurseries, primary schools, and other units identify a clustered or epidemic outbreak of HFMD cases, a report should be made within 24 hours to the local county (district) level CDC

+ Delayed report $=$ report the clustered or epidemic outbreak to CDC $>24$ hours

$\neq$ Timely report $=$ report the clustered or epidemic outbreak to CDC $\leq 24$ hours

reported), ${ }^{29}$ three studies collected samples from all symptomatic cases, ${ }^{28,36,37}$ and other studies collected specimens from a sample of symptomatic cases (method of selection was not reported across these studies). ${ }^{22-27,30-35}$

\section{Detection and diagnosis}

All included studies reported the use of laboratory diagnostic tools to detect EV71 strains as the aetiological agent for HFMD (Table 3), although only seven studies specified the approach, with six using polymerase chain reaction (PCR)-based detection, ${ }^{24-27,29,37}$ and two using immunodiagnosis. ${ }^{30,34}$ The EV71 strain was detected in all studies, with a mean detection rate of $56.7 \%$ (range, $7.6 \%-100 \%$ ), and CA16 strain was detected in two studies, ${ }^{22,28}$ with a mean detection rate of $1.9 \%$ (range, $0 \%-11.76 \%$ ). The majority of the studies collected specimens and tested a selection of symptomatic cases only. Wang et $\mathrm{al}^{29}$ reported that $8.9 \%$ were symptomatic and $7.6 \%$ cases were asymptomatic after testing a selection of symptomatic and asymptomatic cases.

\section{Control measures}

All studies provided some description of the public health measures applied during the outbreak. These measures could be referenced to the "Management guide for clustered and epidemic hand, foot and mouth disease outbreak" shown in Table $4^{22-37}$ and Appendix. ${ }^{40}$ The most frequently implemented public health control measures included environmental disinfection (all 16 studies) and facility closure (14 
studies), with the latter usually last for 2 weeks (range, 6-30 days). Other commonly reported measures were promotion of personal or hand hygiene (9 studies), isolation of symptomatic cases (15 studies), body check (11 studies), and health education (14 studies). Various approaches are summarised in Table 4.

\section{The impact of control interventions on outbreaks}

Given the limited number of included studies with frequently missing information and the wide range of reported contexts and control measures, it is difficult to make any meaningful comparison of outbreak characteristics (eg attack rate and duration) and the use and timeliness of specific interventions across studies. It is, however, worth noting that the mean attack rate for the three studies with timely notification to the CDC was $4.0 \%$ (range, $3.1 \%$ $5.2 \%)^{30,32,37}$ The mean attack rate for the four studies with delayed outbreak report to the CDC was $15.1 \%$ (range, 3.8\%-28.2\%). ${ }^{24,33,34,36}$

In addition, the study by Jiang ${ }^{24}$ identified deliberate misreporting of patient names and kindergartens for symptomatic cases at hospitals or clinics during HFMD check-up. This was because isolation measures for symptomatic cases could stigmatise a child and their family within their community.

\section{Discussion}

\section{Main findings of this study}

The purpose of this review was to investigate the role, impact, and effectiveness of detection methods and public health control measures within childcare centres for children aged $\leq 6$ years. All the included studies applied a list of management practices advised by the China $\mathrm{CDC}$ after epidemiological investigation and risk assessment. Of these studies, central to HFMD outbreak investigation was the effectiveness of identification, reporting, and response with the implementation of appropriate control measures to minimise its spread and incidence. In this review, similar outbreak progression and population characteristics were evident across studies.

According to the China CDC, a clustered outbreak is defined as two or more HFMD cases in the same class or five or more cases within the whole facility ${ }^{40}$ Timely notification of a clustered outbreak within 24 hours to the China CDC was crucial to shortening length of outbreak and attack rate. ${ }^{40}$ Length of outbreak with timely notification $(\leq 24$ hours) could be shortened to 6 days with a lower attack rate and number of classroom units affected within the facility ${ }^{37}$ compared with late notification ( $>24$ hours) of over 2 weeks. ${ }^{33,34,36}$

Effective communication, environmental disinfection, and sanitation instructed by the facility and control supervision from the local CDC may be another reason for the disparity in attack rates and length of outbreak between these facilities. Outbreak control response showed a similar trend to length of outbreak suggesting its influence on main outbreak characteristics (Tables 2 and 4). The China CDC 2012 prevention and control guideline ${ }^{40}$ advised a 24-hour outbreak report, epidemiological investigation, and prevention enforcement such as isolation of symptomatic cases (infected children must stay home until symptoms resolve), improved regular body checks, environmental disinfection, and facility closure following risk assessment.

Asymptomatic healthy carriers (7.62\%) could serve as a source of a HFMD outbreak, according to laboratory results from both symptomatic and asymptomatic cases. ${ }^{29}$ Early isolation of symptomatic individuals was the most effective means of containing the spread of HFMD. ${ }^{6}$ These measures were employed in all studies immediately after identification of the first case. In two studies, affected children were only allowed to return following medical proof of recovery. ${ }^{24,26}$ Full or partial facility closure was recommended by the China CDC where there was failure to contain spread within affected classes using isolation and environmental disinfection measures. ${ }^{41}$ Compared with facility or class closure, the socio-economic impact of isolating symptomatic cases and environmental disinfection on parents and kindergartens is likely to be lower.

The majority of the existing research focuses on the virology and immunology of epidemic strains. It is known that EV71 and CA16 have prolonged survival on a contaminated object or environment surfaces for up to 3 days with $90 \%$ relative humidity. ${ }^{42}$ Environmental disinfection of classrooms, common areas, or commonly shared objects is therefore likely to play an important role in interrupting HFMD transmission. No studies recommended a specific cleaning method or reagent for EV71 inactivation. A non-enveloped virus like EV71 is resistant to common disinfectants, eg $70 \%$ alcohol and $1 \%$ quaternary ammonium compounds. ${ }^{43}$ Kadurugamuwa and Shaheen ${ }^{44}$ recommended the use of "sodium hypochlorite at a concentration of $3120 \mathrm{ppm}$ for 5 minutes" for effective cleaning to reduce the viral load of EV71 or CA16 and minimise the risk of environmental spread during HFMD outbreaks.

Real-time PCR was widely used for EV71 or CA16 detection in past international outbreaks to provide a cheaper and rapid confirmation of the pathogen within 3 hours and with high accuracy, ${ }^{45-47}$ and is recommended by the WHOWPR Office. ${ }^{6}$ Nonetheless, a standardised evaluation system is required to compare their reliability to identify the pathogen in different outbreak settings. ${ }^{6}$ 
TABLE 4. Key control measures highlighted in included studies ${ }^{22-37}$

\begin{tabular}{|c|c|c|c|c|c|c|c|c|}
\hline Study & $\begin{array}{l}\text { Facility } \\
\text { closure* }^{*}\end{array}$ & $\begin{array}{l}\text { Environment } \\
\text { disinfectiont }\end{array}$ & $\begin{array}{c}\text { Hygiene } \\
\text { (personal/ } \\
\text { hand) }\end{array}$ & $\begin{array}{l}\text { Isolation of } \\
\text { HFMD cases } \\
\text { until symptoms } \\
\text { resolved }\end{array}$ & $\begin{array}{c}\text { Health } \\
\text { education§ }\end{array}$ & $\begin{array}{c}\text { Communication } \\
\text { highlighted§ }\end{array}$ & $\begin{array}{c}\text { Body } \\
\text { check } \\
\text { (AM/PM } \\
\text { session)† }\end{array}$ & $\begin{array}{c}\text { Other } \\
\text { measuresll }\end{array}$ \\
\hline
\end{tabular}

(1) Environmental disinfection and isolation measures
Li et al, ${ }^{37}$
6 Days
Yes (daily)

2011

(2) Personal hygiene, environmental disinfection, and isolation measure

\begin{tabular}{|c|c|c|c|c|c|c|}
\hline $\begin{array}{l}\text { Tao et al, }{ }^{28} \\
2009\end{array}$ & 2 Weeks & Yes & - & Yes & Yes & $\begin{array}{c}\text { Yes (with } \\
\text { patient's parents) }\end{array}$ \\
\hline
\end{tabular}

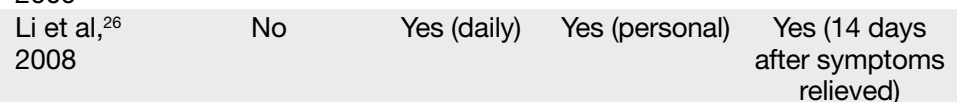

(3) All measures except hand hygiene (facility closure, environmental disinfection, isolation, morning body check)

\begin{tabular}{|c|c|c|c|c|c|c|c|c|}
\hline $\begin{array}{l}\text { Duan et al, }{ }^{22} \mathrm{~F} \\
2010\end{array}$ & $\begin{array}{l}\text { ull, partial, and } \\
\text { no closureף }\end{array}$ & Yes & - & Yes & Yes & $\begin{array}{l}\text { Yes (with } \\
\text { parents) }\end{array}$ & $\begin{array}{l}\text { Yes (AM } \\
\text { and PM) }\end{array}$ & $\begin{array}{l}\text { Yes (active case } \\
\text { searching) }\end{array}$ \\
\hline $\begin{array}{l}\text { Jiang, }{ }^{24} \\
2011\end{array}$ & 10 Days & $\begin{array}{l}\text { Yes (record } \\
\text { kept) }\end{array}$ & - & Yes & Yes (for parents) & Yes (with CDC) & - & $\begin{array}{c}\text { Yes (active case } \\
\text { searching) }\end{array}$ \\
\hline $\begin{array}{l}\text { Wang et al, }{ }^{29} \\
2010\end{array}$ & 2 Weeks & Yes & - & $\begin{array}{c}\text { Yes (for } \\
\text { symptomatic and } \\
\text { asymptomatic } \\
\text { children) }\end{array}$ & $\begin{array}{l}\text { Yes (for parents } \\
\text { and community) }\end{array}$ & - & - & $\begin{array}{l}\text { Yes (test } \\
\text { asymptomatic } \\
\text { cases and } \\
\text { recommend } \\
\text { isolation) }\end{array}$ \\
\hline Wu, ${ }^{30} 2011$ & 2 Weeks & Yes & - & $\begin{array}{l}\text { Yes (1 week } \\
\text { after symptoms } \\
\text { resolved) }\end{array}$ & $\begin{array}{l}\text { Yes (for staff and } \\
\text { parents) }\end{array}$ & Yes (with CDC) & $\begin{array}{l}\text { Yes (AM } \\
\text { and PM) }\end{array}$ & - \\
\hline
\end{tabular}

(4) All measures (facility closure, environmental disinfection, hygiene, isolation, morning body check)
Qu, ${ }^{23} 2010$
2 Weeks
Yes
Yes (personal)
Yes (1 week
Yes (for staff and after symptom parents)
Yes (with CDC
Yes (AM)
Yes (good resolved)
ventilation, forbid
class sleeping
in same room at same time)

$\begin{array}{llccccc}\begin{array}{l}\text { Li et al, }{ }^{25} \\ 2010\end{array} & 30 \text { Days } & \text { Yes } & \begin{array}{c}\text { Yes (hand and } \\ \text { personal) }\end{array} & \begin{array}{c}\text { Yes (2 weeks } \\ \text { after symptoms } \\ \text { resolved) }\end{array} & \begin{array}{c}\text { Yes (for staff, } \\ \text { children, and } \\ \text { parents) }\end{array} & \begin{array}{c}\text { Yes (community } \\ \text { committee with }\end{array} \\ \text { parents) } & \text { Yes (AM) }\end{array}$

\begin{tabular}{|c|c|c|c|c|c|c|}
\hline $\begin{array}{l}\text { Lu et al, }{ }^{27} \\
2008\end{array}$ & 15 Days & Yes & Yes (hand) & Yes & $\begin{array}{l}\text { Yes (for patient's } \\
\text { parents) }\end{array}$ & $\begin{array}{l}\text { Yes (with hospital } \\
\text { and parents) }\end{array}$ \\
\hline
\end{tabular}

In endemic season, ensure good ventilation in classrooms and bedrooms

\begin{tabular}{|c|c|c|c|c|c|c|c|}
\hline $\begin{array}{l}\text { Ge and } L u,{ }^{35} \\
2010\end{array}$ & $\begin{array}{l}\text { Yes (days not } \\
\text { stated) }\end{array}$ & Yes & Yes (personal) & Yes & Yes (for parents) & Yes (with CDC) & $\begin{array}{l}\text { Yes (AM } \\
\text { and PM) }\end{array}$ \\
\hline $\begin{array}{l}\text { Yu et al, }{ }^{31} \\
2009\end{array}$ & 2 Weeks & Yes & Yes (personal) & Yes & Yes (for parents) & - & - \\
\hline
\end{tabular}

\begin{tabular}{|c|c|c|c|c|c|c|c|c|}
\hline & & & & ld & & & & \\
\hline $\begin{array}{l}\text { Zhang and } \\
\text { Ren, }^{33} 2010\end{array}$ & 2 Weeks & Yes & Yes (personal) & Yes & Yes (for parents) & - & $\begin{array}{l}\text { Yes (AM } \\
\text { and PM) }\end{array}$ & $\begin{array}{l}\text { Yes (strengthen } \\
\text { case reporting) }\end{array}$ \\
\hline $\begin{array}{l}\text { Zhang et } \\
\text { al, }^{34} 2001\end{array}$ & No & Yes & Yes & Yes & Yes & $\begin{array}{l}\text { Yes (with CDC } \\
\text { and community } \\
\text { health centre) }\end{array}$ & Yes (AM) & $\begin{array}{c}\text { Yes (stop } \\
\text { admission and } \\
\text { active case } \\
\text { searching) }\end{array}$ \\
\hline
\end{tabular}

Abbreviations: CDC = Chinese Center for Disease Control and Prevention; HFMD = hand, foot, and mouth disease

* CDC 2012 guideline Article 8: The county (district) CDC should conduct risk assessment in nurseries with clustered and epidemic outbreaks. Affected classes or facilities should be closed. Written advice on prevention and control of outbreaks should be given to parents or guardians, along with health education and instructions to observe their child's condition at home

+ CDC 2012 guideline Article 7: Nurseries with clustered or epidemic outbreaks should perform a more thorough morning health check of children, and identify the reason for a student's absence. Toys, appliances, and eating utensils that have been used by infected children should be disinfected

f CDC 2012 guideline Article 6: According to the patient's clinical condition, medical institutions may require the patient to be confined at home or hospitalised

$\S$ CDC 2012 guideline Article 9: The health administrative department of the area where the outbreaks occur should maintain close collaboration with local educational departments and media to further strengthen surveillance and risk communication. Health education should be improved for guardians and parents of children under 5 years old

II CDC 2012 guideline Article I0: If there is an increasing number of local outbreaks, according to the epidemic situation, the health administrative departments should work with relevant departments to ensure timely evaluation of the outbreak. If an outbreak reaches a certain level, the health emergency response system should be activated promptly

I Facility closure:Among the 6 I kindergartens involved, 18 adopted full facility closure, 22 adopted partial closure of affected classes, and 21 did not close 


\section{Applicability of the findings}

This study reported results from the first systematic review of institution-based public health prevention of HFMD. To date, little is known about the impact of various health prevention practices. The findings from this review derive mainly from studies in China which has a loose cross-border relationship with HKSAR regarding climate pattern, culture, and ethos. ${ }^{48} \mathrm{~A}$ series of political events has increased the population mix in Hong Kong at a social, economic, and cultural level since Hong Kong was returned to China as a special administrative region in 1997.48-50 Under the 'One Way Permit Scheme', the influx of 150 immigrants daily from China to reside in Hong Kong has increased the population mix across the border. ${ }^{50}$ The number of cross-border newborns increased under the Basic Law Article 24 that states Chinese citizens born in Hong Kong enjoyed the right of abode regardless of their parents' immigration status until the enforcement of the "Zero quota" policy for births to non-local pregnant women for delivery in Hong Kong on 1 January 2013.49,51 By 2016, these newborns had become cross-border students who accounted for $20 \%$ of the kindergarten population in Hong Kong, a rise of $30 \%$ since 2011..$^{52,53}$

The findings from this review are likely to be of value and to inform policymakers to control HFMD in Hong Kong childcare institutions. In Hong Kong, one important difference is the private nature of childcare facilities compared with publicoperated facilities. ${ }^{54}$ The kindergartens must bear the financial cost of preventive resources within an already-limited budget to operate the facility itself. Most cannot afford to hire a public health specialist to coordinate infection control measures from notification to implementation of interventions within the facility. On the contrary, most public kindergartens in China received extra support, for example, a school doctor on duty to communicate with the $\mathrm{CDC}$ and reinforce these guidelines during a HFMD outbreak. ${ }^{25,26,32}$

\section{Limitations of this study}

There were some limitations in this review. First, the aim and objective of some studies were more biological and aetiological in nature and less concerned with the focus on the review of effectiveness and impact of intervention. ${ }^{23,37}$ Different versions of the China CDC prevention and control guidelines were applied in different studies to define outcome measures. Included studies were heterogeneous and focused on different aspects of public health. ${ }^{40,55,56}$

Second, insufficient data were provided to assess the risk factors, effectiveness, and impact of multiple strategic measures, either as a combined or separate approach in outbreak detection and control.
Only two included studies interpreted and analysed the OR for potential risk factors, where younger age, direct contact with HFMD cases, and travelling on the school bus would heighten the risk of HFMD infection..$^{25,26}$ In contrast, other studies proposed risk factors but did not further analyse them or provide statistical evidence..$^{22-24,27-37,57,58}$ For example, morning body check and health education were described in detail, but their effectiveness and impact were hardly measured which is inappropriate in the context of outbreak investigations (Table 4). ${ }^{22-37}$ Dates for implementation of control measures and notification of outbreaks were often not reported, meaning that delays between outbreak onset and response could not be estimated in most studies. Most studies did not quantify 'effectiveness' at different time points of the detection process, nor discuss further the value of these outbreak detection methods in managing a HFMD outbreak.

Third, all included studies concerned children in a kindergarten in various provinces of China. Apart from public and private kindergartens in China, there are few data about outbreak management at child daycare centres or other paediatric care facilities. ${ }^{3,59}$ Evidence available from other countries has derived mostly from community surveillance or outbreaks among wider population age-groups, without laboratory confirmation of EV71 as the causative strain, and were therefore excluded from this review. $7,44,58,60-65$

\section{Recommendations for future outbreaks \\ Cost-effectiveness studies and mathematical modelling}

Wang et $\mathrm{a}^{29}$ pointed out that $7.62 \%$ of asymptomatic cases acted as carriers for transmission within the kindergarten. Two studies mentioned the contribution of asymptomatic cases to HFMD transmission in a kindergarten, but no further tests were conducted to confirm their presence. ${ }^{28,33}$ It is possible that the attack rate across studies could be underestimated due to the presence of asymptomatic cases. To investigate the incidence of asymptomatic cases and their serological characteristics, a prospective cohort study of EV71 immunity status could be conducted using a neutralisation test against EV71 to measure the herd EV71 immunity level within the community before and at different time intervals after an outbreak.

A compartment disease transmission model suggested by Roy and Halder ${ }^{66}$ could be used to explore the relationship in the modelled population that may include EV71 susceptible cases, infective symptomatic cases, infective asymptomatic cases, and recovered cases at an initial time and the disease transmission rate at any given time. The model could reveal the impact of asymptomatic cases and the 
epidemic potential at different time points of the outbreak.

Furthermore, a cost-effectiveness study could be conducted to identify a cheap, quick, accurate, and user-friendly diagnostic tool that can be applied to a large population to actively search for asymptomatic cases, for example, a rapid antigen detection kit for EV71.

To compare the effectiveness of different public health measures, we could apply a spatial deterministic epidemic model to all the kindergartens located in each of the 18 districts in Hong Kong. ${ }^{67}$ It is possible to assess the effectiveness of basic (eg personal health measure, health education) and contingency public health control measures (isolation, facility closure) implemented during the epidemic. ${ }^{67}$ At the same time, the model can explore the expected impact of an isolation or facility closure policy depending on when it is implemented. ${ }^{67}$

To facilitate early warning and implementation of precautions, $\mathrm{Li}$ et $\mathrm{al}^{37}$ recommended the use of molecular epidemiological analysis of EV71 genotypes using the VP1 sequence database as described in their study. The geographical and evolution origin, transmission pattern, and current prevalence strains could be detected by comparing genetic variation between EV71 strains. ${ }^{37}$

\section{Policy recommendations}

At the moment, a standard guideline on prevention of communicable diseases within childcare facilities and two letters to kindergartens with a hotline number to warn about the disease is the only information issued by the CHP. The following measures should be incorporated into future HFMD prevention and control policy in Hong Kong.

(1) A clear definition of an outbreak should be developed for individual and clustered outbreaks. Currently, there is only a section for the definition of an outbreak of communicable diseases, and a brief definition provided in a letter to kindergartens.

(2) As the key government agency for infection control and public health practice, CHP should work with the Hospital Authority and other health care providers to obtain consent from parents to gain timely access to the relevant medical records and laboratory results. This would accelerate confirmation of the source and subsequent cases in an outbreak.

(3) Epidemiological investigation is important for risk assessment during a HFMD outbreak to inform subsequent preventive measures. A guideline should be developed on how and when it should be carried out. As with the China CDC, the CHP should initiate an investigation within 24 hours at an affected facility upon the report of a clustered outbreak.
(4) "Enhance health surveillance" is mentioned in the guideline for children without symptoms at the facilities. ${ }^{14} \mathrm{~A}$ more active surveillance plan that will enable identification of symptomatic and asymptomatic cases during an HFMD outbreak should be developed.

(5) The government should provide incentives to encourage childcare facilities to train extra staff as 'infection control specialists'. These specialists will act as the first contact, knowledge, and communication points to exchange information and support stakeholders during a communicable disease epidemic. They should be invited to attend CHP's regular seminar and training workshops about current communicable diseases and provide a forum to exchange ideas and discuss prevention methods.

(6) Although a response team is available for different communicable diseases, information is not immediately made public. To improve communication and transparency, an online interactive forum should be developed where parents, childcare facilities, and a CHP specialist team can exchange news of communicable diseases and the appropriate measures taken. The 24-hour hotline and notification forms are not interactive nor an effective means of communication across stakeholders.

\section{Conclusions}

Timely notification of a clustered outbreak within 24 hours and implementation of isolation measures according to the CDC guidelines are crucial to minimise attack rate of HFMD within childcare facilities. To achieve this, communication between stakeholders (childcare facilities, CHP, parents, and health care providers) about outbreak confirmation, risk assessment, and sentinel surveillance in the form of regular body checks should be enhanced by the provision of clear guidelines and an interactive platform. Findings from this review informed us of more comprehensive HFMD policy and practices to apply in Hong Kong that, similar to the China CDC framework, will improve disease communication. The government should provide incentives for childcare facilities to train public health specialists to coordinate infection control measures from notification to implementation of the intervention and enforce the guideline within the facility. In China, the health specialist facilitates communication between the CDC and kindergarten, enables accelerated outbreak notification, and effectively manages control efforts. ${ }^{25,26,32}$ In light of all the missing information in the included studies, standardised reporting and outbreak investigation guidelines could be established. It should be provided in both a paper and electronic format and 
shared across all childcare facilities in Hong Kong monitored by the CHP response team to generate more timely, comprehensive, and comparable evidence during outbreaks. Future research could generate more robust evidence for the effectiveness of different control practices using a spatial deterministic epidemic model. Applied across all kindergartens located in each of the 18 districts in Hong Kong, it could assess the effectiveness of basic (eg personal health measures, health education) and contingency public health control measures.

\section{Declaration}

All authors have disclosed no conflicts of interest.

\section{Appendix}

Additional material related to this article can be found on the HKMJ website. Please go to <http:// www.hkmj.org >, and search for the article.

\section{References}

1. Western Pacific Regional Office of World Health Organization. Hand, foot, and mouth disease situation update. Available from: http://www.wpro.who.int/ emerging_diseases/hfmd_biweekly_29dec2014.pdf. Accessed 29 Mar 2015.

2. Hand, foot and mouth disease (HFMD). Centre for Health Protection, Department of Health of the Hong Kong SAR Government. Communicable Diseases Watch 2015;12(4):17.

3. Ruan F, Yang T, Ma H, et al. Risk factors for hand, foot, and mouth disease and herpangina and the preventive effect of hand-washing. Pediatrics 2011;127:e898-904.

4. Hand, foot and mouth disease (HFMD). Centre for Health Protection, Department of Health of the Hong Kong SAR Government. Communicable Diseases Watch 2016;13(4):17.

5. Lee MS, Lin TY, Chiang PS, et al. An investigation of epidemic enterovirus 71 infection in Taiwan, 2008: clinical, virologic, and serologic features. Pediatr Infect Dis J 2010;29:1030-4.

6. Western Pacific Regional Office of World Health Organization. A guide to clinical management and public health response for hand, foot and mouth disease. Available from: http://www.wpro.who.int/publications/ docs/GuidancefortheclinicalmanagementofHFMD.pdf. Accessed 16 Mar 2013.

7. Ma E, Chan KC, Cheng P, Wong C, Chuang SK. The enterovirus 71 epidemic in 2008-public health implications for Hong Kong. Int J Infect Dis 2010;14:e77580.

8. Tsao KC, Chan EC, Chang LY, et al. Responses of IgM for enterovirus 71 infection. J Med Virol 2002;68:574-80.

9. Cardosa MJ, Perera D, Brown BA, et al. Molecular epidemiology of human enterovirus 71 strains and recent outbreaks in the Asia-Pacific region: comparative analysis of the VP1 and VP4 genes. Emerg Infect Dis 2003;9:4618.

10. McMinn P, Lindsay K, Perera D, Chan HM, Chan KP, Cardosa MJ. Phylogenetic analysis of enterovirus 71 strains isolated during linked epidemics in Malaysia, Singapore, and Western Australia. J Virol 2001;75:7732-8.

11. Bible JM, Pantelidis P, Chan PK, Tong CY. Genetic evolution of enterovirus 71: epidemiological and pathological implications. Rev Med Virol 2007;17:371-9.

12. Shimizu H, Utama A, Onnimala N, et al. Molecular epidemiology of enterovirus 71 infection in the Western Pacific Region. Pediatr Int 2004;46:231-5.

13. Zhang Y, Tan X, Cui A, et al. Complete genome analysis of the $\mathrm{C} 4$ subgenotype strains of enterovirus 71: predominant recombination $\mathrm{C} 4$ viruses persistently circulating in China for 14 years. PLoS One 2013;8:e56341.

14. Centre for Health Protection, Department of Health of the Hong Kong SAR Government. Guidelines on Prevention of Communicable Diseases in Schools/ Kindergartens/ Kindergartens-cum-Child Care Centers/Child Care Centres 2011. Available from: http://www.chp.gov.hk/ files/pdf/guidelines_on_prevention_of_communicable_ diseases_in_schools_kindergartens_kindergartens_cum_ child_care-centres_child_are_centres.pdf. Accessed 20 Sep 2012.

15. Hand, foot and mouth disease (HFMD). Centre for Health Protection, Department of Health of the Hong Kong SAR Government. Communicable Diseases Watch 2017;14(2):6-7.

16. Reed Z, Cardosa MJ. Status of research and development of vaccines for enterovirus 71. Vaccine 2016;34:2967-70.

17. Lu S. EV71 vaccines: a milestone in the history of global vaccine development. Emerg Microbes Infect 2014;3:e27.

18. Kim KH. Enterovirus 71 infection: an experience in Korea, 2009. Korean J Pediatr 2010;53:616-22.

19. Chang LY, King CC, Hsu KH, et al. Risk factors of enterovirus 71 infection and associated hand, foot, and mouth disease/herpangina in children during an epidemic in Taiwan. Pediatrics 2002;109:e88.

20. Critical Appraisal Skills Programme: Making sense of evidence. Available from: http://www.casp-uk.net/. Accessed 12 Feb 2013.

21. Wong WC, Cheung CS, Hart GJ. Development of a quality assessment tool for systematic reviews of observational studies (QATSO) of HIV prevalence in men having sex with men and associated risk behaviours. Emerg Themes Epidemiol 2008;5:23.

22. Duan SB, Ren LQ, Shi ZM. Analysis of clustered outbreaks of hand foot and mouth disease in Jining City in 2009 [in Chinese]. South China J Prev Med 2010;36(2):379,41 .

23. Qu H. Analysis of emergency of hand foot and mouth disease in Zhongshan District in Dalian City in 2009 [in Chinese]. Prev Med Trib 2010;16(3):277-8.

24. Jiang QS. Outbreak investigation of an outbreak of hand foot and mouth disease in a kindergarten in Zhengzhou City [in Chinese]. China Mod Doct 2011;49(2):85,120.

25. Li MZ, Chen YZ, Li P. Epidemiological investigation of an outbreak of hand foot and mouth disease in a kindergarten in Zhengzhou City [in Chinese]. Henan J Prev Med 2010;21(6):461-2,473.

26. Li XY, Si XH, Li LF. Investigation of an outbreak of hand, foot and mouth disease in a kindergarten in Futian District of Shenzhen [in Chinese]. Pract Prev Med 2008;15(6):17878.

27. Lu GY, Liu GP, Yue JL. Report on an outbreak of the handfoot-and-mouth disease epidemic situation [in Chinese]. J 
Public Health Prev Med 2008;19(5):55-6.

28. Tao T, Liu L, Song SP, Zheng JF, Hao YJ. Investigation of an outbreak of hand, foot and mouth disease in a kindergarten of army unit [in Chinese]. Occup Heal 2009;25(19):2087.

29. Wang G, Liu Y, Luo S, Wang T, Zhan J. Epidemiological investigation of an outbreak of hand foot and mouth disease in a kindergarten in Shenzhen, Guangdong [in Chinese]. China Heal Mon 2010;29:82-3.

30. Wu C. Epidemiological survey of an outbreak of HFMD in a kindergarten of Baoshan District [in Chinese]. Occup Heal 2011;27(20):2334-5.

31. Yu HZ, Xiang N, Cui LM, et al. An outbreak of hand-footmouth disease caused by EV71 virus in a kindergarten of Fangshan District in Beijing [in Chinese]. China J Infect Control 2009;8(2):113-4.

32. Zhang HJ, Qin ZK. Epidemiological investigation of an outbreak of hand foot and mouth disease in a kindergarten [in Chinese]. Jiangsu J Prev Med 2007;18(2):15.

33. Zhang J, Ren HY. Epidemiological investigation of an outbreak of hand foot and mouth disease in a kindergarten [in Chinese]. Occup Heal 2010;26(3):328-9.

34. Zhang A, Li Y, Zhang J, et al. Investigation of an outbreak of EV71 hand foot and mouth disease [in Chinese]. Shanghai J Prev Med 2001;13(12):587-8.

35. Ge GX, Lu L. Survey on outbreak of hand-foot-mouth disease at a kindergarten in Gangcheng District, Laiwu City, 2008 [in Chinese]. Lit Inf Prev Med 2010;16(9):764,847.

36. Chen H, Situ CM, Tian HW. Investigation of an outbreak of hand foot and mouth disease in children [in Chinese]. J Prev Med Inf 2007;23:364-5.

37. Li J, Jia L, Liu JR, et al. Epidemiological and etiological characteristics of hand foot and mouth disease cluster in a kindergarten in Beijing, 2010. Dis Surveill 2011;26:790-3.

38. Merlin T, Weston A, Tooher R. Extending an evidence hierarchy to include topics other than treatment: revising the Australian 'levels of evidence'. BMC Med Res Methodol 2009;9:34.

39. China Internet Information Center. Administrative division system 2016. Available from: http://www.china. org.cn/english/feature/38436.htm. Accessed 21 Apr 2016.

40. Chinese Center for Disease Control and Prevention. Management guide for clustered and epidemic hand, foot and mouth disease outbreak (2012 version) [in Chinese]. Available from: http://www.chinacdc.cn/jkzt/crb/szkb/ jszl_2275/201206/t20120629_63852.htm. Accessed 15 Jul 2012.

41. Chinese Center for Disease Control and Prevention. EV71 infection diagnostic and treatment guide (2008 version) [in Chinese]. Available from: http://www.chinacdc.cn/ jkzt/crb/szkb/jszl_2275/200805/t20080506_24703.htm. Accessed 5 Jul 2012.

42. Wong SS, Yip CC, Lau SK, Yuen KY. Human enterovirus 71 and hand, foot and mouth disease. Epidemiol Infect 2010;138:1071-89.

43. Chan YF, Abu Bakar S. Virucidal activity of Virkon S on human enterovirus. Med J Malaysia 2005;60:246-8.

44. Kadurugamuwa JL, Shaheen E. Inactivation of human enterovirus 71 and coxsackie virus A16 and hand, foot, and mouth disease. Am J Infect Control 2011;39:788-9.

45. Tan EL, Yong LL, Quak SH, Yeo WC, Chow VT, Poh CL. Rapid detection of enterovirus 71 by real-time TaqMan RT-PCR. J Clin Virol 2008;42:203-6.

46. Fujimoto T, Yoshida S, Munemura T, et al. Detection and quantification of enterovirus 71 genome from cerebrospinal fluid of an encephalitis patient by PCR applications. Jpn J Infect Dis 2008;61:497-9.

47. Xiao XL, He YQ, Yu YG, et al. Simultaneous detection of human enterovirus 71 and coxsackievirus A16 in clinical specimens by multiplex real-time PCR with an internal amplification control. Arch Virol 2009;154:121-5.

48. Kennedy KJ. Immigration and Hong Kong: "New immigrants" and ethnic minorities. Hong Kong report prepared for the UNESCO-KEDI Regional Policy Seminar 2012-Education policy: Making in the age of migration in Asia and the Pacific; 2012 Jul 10-12: 8.

49. The Basic Law of the Hong Kong SAR Government. Chapter III: Fundamental rights and duties of the residents. Available from: http://www.basiclaw.gov.hk/en/ basiclawtext/chapter_3.html. Accessed 10 Jan 2017.

50. One-way Permit Scheme [press release]. The Hong Kong SAR Government; 2014 Jan 22.

51. Government reaffirms its strict enforcement of the "zero quota" policy [press release]. The Hong Kong SAR Government; 2012 Dec 28.

52. Cross-border students up $118 \%$ in five years. Harbour Times. 2016 Jun 23.

53. Education Bureau of the Hong Kong SAR Government. Student enrolment statistics, 2015/16 (kindergarten, primary and secondary levels). Available from: http://www. edb.gov.hk/attachment/en/about-edb/publications-stat/ figures/Enrol_2015.pdf. Accessed 10 Jan 2017.

54. Education Bureau of the Hong Kong SAR Government. Overview of kindergarten education in Hong Kong. Available from: http://www.edb.gov.hk/en/edu-system/ preprimary-kindergarten/overview/index.html. Accessed 26 Aug 2015.

55. Chinese Center for Disease Control and Prevention. Hand, foot and mouth disease prevention and control guideline (2009 version) [in Chinese]. Available from: http://www.chinacdc.cn/jkzt/crb/szkb/jszl_2275/200906/ t20090612 24707.htm. Accessed 10 Jul 2012.

56. Chinese Center for Disease Control and Prevention. Hand foot and mouth disease as notifiable disease notification by Health Bureau [in Chinese]. Available from: http:// www.chinacdc.cn/jkzt/crb/szkb/jszl_2275/200805/ t20080506_24699.htm. Accessed 3 Jul 2012.

57. Goh KT, Doraisingham S, Tan JL, Lim GN, Chew SE. An outbreak of hand, foot, and mouth disease in Singapore. Bull World Heal Organ 1982;60:965-9.

58. Chen KT, Chang HL, Wang ST, Cheng YT, Yang JY. Epidemiologic features of hand-foot-mouth disease and herpangina caused by enterovirus 71 in Taiwan, 19982005. Pediatrics 2007;120:e244-52.

59. Nguyen NT, Pham HV, Hoang CQ, et al. Epidemiological and clinical characteristics of children who died from hand, foot and mouth disease in Vietnam, 2011. BMC Infect Dis 2014;14:341.

60. Edmond M, Wong C, Chuang SK. Evaluation of sentinel surveillance system for monitoring hand, foot and mouth disease in Hong Kong. Public Health 2011;125:777-83.

61. Sarma N, Sarkar A, Mukherjee A, Ghosh A, Dhar S, Malakar R. Epidemic of hand, foot and mouth disease in West Bengal, India in August, 2007: a multicentric study. Indian J Dermatol 2009;54:26-30.

62. Ooi EE, Phoon MC, Ishak B, Chan SH. Seroepidemiology of human enterovirus 71, Singapore. Emerg Infect Dis 
2002;8:995-7.

63. Chakraborty R, Iturriza-Gómara M, Musoke R, Palakudy T, D'Agostino A, Gray J. An epidemic of enterovirus 71 infection among HIV-1-infected orphans in Nairobi. AIDS 2004;18:1968-70

64. Shimizu H, Okuyama K, Hirai Y. Epidemic of hand, foot and mouth disease in Kawasaki City, Japan. Jpn J Infect Dis 2005;58:330-1.

65. Wu PC, Huang LM, Kao CL, Fan TY, Cheng AL, Chang LY.
An outbreak of coxsackievirus A16 infection: comparison with other enteroviruses in a preschool in Taipei. J Microbiol Immunol Infect 2010;43:271-7.

66. Roy N, Halder N. Compartmental modeling of hand, foot and mouth infectious disease (HFMD). Res J Appl Sci 2010;5:177-82.

67. Chowell G, Hyman JM. Mathematical and statistical modeling for emerging and re-emerging infectious diseases. US: Springer International Publishing Switzerland; 2016. 